\title{
Expression of ion transport-associated proteins in human efferent and epididymal ducts
}

\author{
Minna Kujala ${ }^{1,2}$, Satu Hihnala ${ }^{1,3}$, Jukka Tienari ${ }^{4}$, Kari Kaunisto ${ }^{5}$, Johanna Hästbacka ${ }^{1,3}$, \\ Christer Holmberg ${ }^{3}$, Juha Kere ${ }^{1,6}$ and Pia Höglund ${ }^{1,3}$ \\ ${ }^{1}$ Department of Medical Genetics, University of Helsinki, Helsinki, Finland, ${ }^{2}$ Helsinki University Central Hospital \\ Laboratory Division, Helsinki, Finland, ${ }^{3}$ Hospital for Children and Adolescents, University of Helsinki, Helsinki, \\ Finland, ${ }^{4}$ Department of Pathology, Helsinki University Central Hospital/Peijas Hospital and HUSLAB, Vantaa, \\ Finland, ${ }^{5}$ Departments of Anatomy and Cell Biology and Pediatrics, University of Oulu, Oulu, Finland and \\ ${ }^{6}$ Department of Biosciences at Novum, Karolinska Institute, Stockholm, Sweden
}

Correspondence should be addressed to M Kujala, Department of Medical Genetics, POB 63, 00014 University of Helsinki, Finland; Email: minna.kujala@helsinki.fi

\begin{abstract}
Appropriate intraluminal microenvironment in the epididymis is essential for maturation of sperm. To clarify whether the anion transporters SLC26A2, SLC26A6, SLC26A7, and SLC26A8 might participate in generating this proper intraluminal milieu, we studied the localization of these proteins in the human efferent and the epididymal ducts by immunohistochemistry. In addition, immunohistochemistry of several SLC26-interacting proteins was performed: the $\mathrm{Na}^{+} / \mathrm{H}^{+}$exchanger 3 (NHE3), the $\mathrm{Cl}^{-}$channel cystic fibrosis transmembrane conductance regulator (CFTR), the proton pump V-ATPase, their regulator $\mathrm{Na}^{+} / \mathrm{H}^{+}$exchanger regulating factor 1 (NHERF-1), and carbonic anhydrase II (CAII). Our results show that SLC26A6, CFTR, NHE3, and NHERF-1 are co-expressed on the apical side of the nonciliated cells, and SLC26A2 appears in the cilia of the ciliated cells in the human efferent ducts. In the epididymal ducts, SLC26A6, CFTR, NHERF-1, CAII, and V-ATPase (B and E subunits) were co-localized to the apical mitochondria rich cells, while SLC26A7 was expressed in a subgroup of basal cells. SLC26A8 was not found in the structures studied. This is the first study describing the localization of SLC26A2, A6 and A7, and NHERF-1 in the efferent and the epididymal ducts. Immunolocalization of human CFTR, NHE3, CAII, and V-ATPase in these structures differs partly from previous reports from rodents. Our findings suggest roles for these proteins in male fertility, either independently or through interaction and reciprocal regulation with co-localized proteins shown to affect fertility, when disrupted.

Reproduction (2007) 133 775-784
\end{abstract}

\section{Introduction}

Optimal microenvironment in each segment of the male reproductive tract is essential for successful maturation and correct motility of sperm and, thereby, for male fertility. Testicular fluid carries immature spermatozoa to the efferent ducts (Wong et al. 2002), where majority $(>95 \%)$ of the fluid is reabsorbed (Clulow et al. 1998, Wong et al. 2002). During passage through the epididymal ducts, the composition of the luminal fluid is further gradually changed by sequential absorption and secretion processes (Turner 2002, Wong et al. 2002). Water absorption in efferent ducts is allowed by interdependent transport of $\mathrm{Cl}^{-}$and $\mathrm{Na}^{+}$, which may be mediated by an apical anion $\mathrm{Cl}^{-} / \mathrm{HCO}_{3}^{-}$ exchanger, in parallel with a $\mathrm{Na}^{+} / \mathrm{H}^{+}$antiporter (Hansen et al. 2004).
Accurate control of intraluminal $\mathrm{pH}$ and $\mathrm{HCO}_{3}^{-}$ concentration is needed for inducing the sperm motility and, on the other hand, for keeping sperm quiescence during the storage in epididymis (Litvin et al. 2003, Gadella \& Van Gestel 2004). In rats, luminal pH and $\mathrm{HCO}_{3}^{-}$concentration decrease in the distal segments of the efferent ducts, and further diminish along the epididymal ducts (Levine \& Marsh 1971, Levine \& Kelly 1978, Newcombe et al. 2000), but only little is known about specific $\mathrm{HCO}_{3}^{-}$transporters mediating these processes.

SLC26 (Solute carrier family no 26) anion exchangers are cell membrane proteins capable of transporting several anions $\left(\mathrm{Cl}^{-}, \mathrm{HCO}_{3}^{-}, \mathrm{OH}^{-}, \mathrm{SO}_{4}^{2-}\right.$, and oxalate) with different specificities. Altogether, 11 human members of this gene family have been discovered, of which 4 (SLC26A2-A5) are known to cause distinct 
hereditary diseases when mutated (Hastbacka et al. 1994, Hoglund et al. 1996, Everett et al. 1997, Lohi et al. 2000, 2002, Toure et al. 2001, Liu et al. 2003 and McKusick (ed) OMIM database which can be viewed online at www. ncbi.nlm.nih.gov/entrez/query.fcgi?db=OMIM). Prior to this work, preliminary information about the expression of five SLC26 members in the human male reproductive tract was available: SLC26A1 (sulphate anion transporter 1; SAT-1), SLC26A3 (down regulated in adenoma; DRA, congenital chloride diarrhea (CLD)), SLC26A4 (pendrin), SLC26A7 and SLC26A8 (testis anion transporter 1; TAT1) in the testis, and SLC26A3 in the seminal vesicle, the efferent, and the epididymal ducts (Haila et al. 2000, Lacroix et al. 2001, Lohi et al. 2002, Regeer et al. 2003, Hihnala et al. 2006). However, excluding SLC26A3 (Hihnala et al. 2006), neither systematic review of the expression profiles of these proteins in the male reproductive system nor their specific expression in certain cell types of the epididymis has been published. Furthermore, subfertility due to low amount of sperm with aberrant mobility are common among male patients with CLD, known to be caused by mutations in A3 member of this SLC26 gene family (Hoglund et al. 2006). Therefore, we proposed that other members of the SLC26 family might play role in human fertility as well, provided that their expression profile would conform to this hypothesis.

As a primary step towards understanding the possible role of the SLC26 protein family in human efferent and epididymal ducts, we searched for the localization of SLC26A2 (diastrophic dysplasia sulfate transporter; DTDST), SLC26A6 (putative anion transporter-1; PAT-1, chloride-formate exchanger; CFEX), SLC26A7, and SLC26A8 in these structures by immunohistochemistry. Furthermore, we studied the human expression of several proteins shown to interact with SLC26 members on molecular level, and known to be involved in fluid and electrolyte absorption or $\mathrm{pH}$ regulation in efferent and/or epididymal ducts in animal studies. This set of proteins included: $\mathrm{Na}^{+} / \mathrm{H}^{+}$exchanger 3 (NHE3, SLC9A3), cystic fibrosis transmembrane conductance regulator (CFTR), $\mathrm{Na}^{+} / \mathrm{H}^{+}$exchanger regulating factor 1 (NHERF-1, SLC9A3R1, EBP50), carbonic anhydrase II (CAII), and V-ATPase (vacuolar-type $\mathrm{H}^{+}$ATPase). Since expression and function of some of these proteins varies greatly between different species (Chernova et al. 2005, Kujala et al. 2005), it is important to study them in human tissues as well.

\section{Materials and Methods}

\section{Tissue samples}

Formalin-fixed, paraffin-embedded human epididymis specimens were obtained from the archives of the Department of Pathology, HUSLAB, Helsinki University Central Hospital. We examined altogether 18 histologically normal adult (22-71 years old, mean value 37) epididymides removed because of testicular tumors (ten seminomas, two teratocarcinomas, one mature teratoma, one embryonal carcinoma and seminoma, one cysta epidermalis, one cystadenoma of rete testis, one cicatrix, and one normal finding). Histological examination revealed complete spermatogenesis in all but two corresponding testis samples.

\section{Antibodies}

Antisera were raised in rabbits against the synthetic peptides TVRDSLTNGEYCKKEEEN for SLC26A2 (antiA2), MDLRRRDYHMERPLLNQEHL for SLC26A6 (antiA6), SHIHSNKNLSKLSDHSEV for SLC26A7 (anti-A7), and VEEVWLPNNSSRNSSPGLPD for SLC26A8 (anti-A8), corresponding to amino acids 689-706, 1-20, 639-656, and 680-699 respectively. Two rabbits were immunized with each peptide. Peptide synthesis and antibody production were purchased from Research Genetics (anti-A2) and Sigma Genosys Ltd (anti-A6, -A7, -A8). The anti-A2, $-A 6$, and $-A 7$ antibodies were purified from whole serum by affinity chromatography (Amersham Pharmacia Biotech). The specificity of these antibodies except for antiA8 has been shown previously (Haila et al. 2001, Lohi et al. 2002, 2003, Kujala et al. 2005).

Commercial polyclonal rabbit antibodies used were: anti-human CAII (200-401-136; Rockland Immunochemicals, Gilbertsville, PA, USA), anti-rat NHE3 (NHE31-A; Alpha Diagnostics, San Antonio, TX, USA), anti-human vacuolar type $\mathrm{H}^{+}$-ATPase B1/2 (V-ATPaseB, sc-20943; Santa Cruz Biotechnology, Heidelberg, Germany), antihuman vacuolar type $\mathrm{H}^{+}$-ATPase E (V-ATPaseE, sc-20946; Santa Cruz Biotechnology), and anti-human NHERF-1 (EBP50, PA1-090; Affinity BioReagents, Golden, CO, USA). In addition, the mouse MAB anti-human CFTR (Ab-2 MM13-4; Neo Markers, Fremont, CA, USA) was used.

\section{Western blotting}

Fresh rat testis was snap frozen in liquid nitrogen and stored in $-18{ }^{\circ} \mathrm{C}$. The frozen sample was homogenized, Laemmli buffer and $\beta$-mercaptoethanol were added and the sample was boiled in $100^{\circ} \mathrm{C}$ for $5 \mathrm{~min}$. The sample was run on $7.5 \%$ SDS-PAGE gel in several parallel wells. The separated proteins were transferred electrophoretically to Hybond-C extra membranes (Amersham Life Sciences). After blocking in 5\% nonfat dry milk and $1 \%$ BSA in Trisbuffered Saline Tween-20 (TBST) for $60 \mathrm{~min}$, the filters were incubated with A8 antiserum (1:50) in $2.5 \%$ nonfat dry milk and $0.5 \%$ BSA in TBST for $1 \mathrm{~h}$. Horseradish peroxidase (HRP) conjugated swine anti-rabbit IgG (Dako, Glostrup, Denmark) was used as a secondary antibody. The corresponding rabbit preimmune serum (1:50) was used as a negative control. The protein bands were visualized by chemiluminescence (ECL Western Blotting Detection Reagents, Amersham Biosciences) detected on X-ray films. 


\section{Immunohistochemistry}

Deparaffinized $5 \mu \mathrm{m}$ human epididymis tissue sections were used in the experiments. The average number of distinct specimens stained with each antibody was nine, and all staining experiments were repeated several times. The peroxidase-antiperoxidase labeling kit (Vectastain Elite ABC Kit, Vector Laboratories, Burlingame, CA, USA) and the two-step peroxidase kit (EnVision + System HRP, DAKO, Carpinteria, CA, USA) were used. The pretreatment for each of the antibodies was individual: boiling in microwave oven in $10 \mathrm{mM}$ citrate buffer ( $\mathrm{pH}$ 6.0) was used for anti-A2, anti-A6, anti-CAll, anti-CFTR, anti-NHE3, and anti-NHERF-1, but anti-A6, anti-A7, anti-VATPaseB, and anti-VATPaseE required no specific pretreatment. For anti-A8 antibody, several different pretreatments were examined, but none resulted in specific signal in the human epididymis.

The pretreatment was followed by blocking of endogenous peroxidase activity with $\mathrm{H}_{2} \mathrm{O}_{2}$, according to the kit manufacturer's directions. The dilutions of the antisera ranged in the ratio from 1:750 to 1:3000 and for the affinity purified antibodies from 0.1 to $20 \mu \mathrm{g} / \mathrm{ml}$. Diaminobenzidine was used as the chromogenic substrate with Mayer's hematoxylin counterstaining. Preimmune sera, normal rabbit IgG or normal mouse IgG were used as the corresponding negative controls, with similar concentrations of $\lg G$ as for the purified antibodies.

\section{Histological classification}

Different cell types were determined by their morphology and location. Analyzing the different types of the efferent ducts was done by following the definitions by Yeung et al. briefly: 1) type I epithelium has an irregular profile with variable height of the epithelial cells, 2) type II epithelium is regular low cuboidal with very few vacuoles, 3 ) type III epithelium is distinguishable by its vacuolated epithelial cells forming tubules with a regular outline, 4) cuboidal type IV epithelium lines, with mosaic pattern, parts of short communal cavities, and 5) type $V$ efferent duct epithelium consists of ciliated columnar cells. Only types I and III form longer segments, while type II is mainly found in short blind end tubules, type $\mathrm{V}$ in brief distal segments close to epididymal ducts, and type IV in short transition segments only. Each of the efferent duct tubule types has both ciliated and nonciliated cells. In addition, basal cells can be found in tubule types I-III (Yeung et al. 1991).

Distinct cell types of the human epididymal ducts were distinguished according to the descriptions of Palacios et al. and Regadera et al. briefly: three morphologically different cell types can be detected; principal cells, apical mitochondria rich cells (AMRC), and basal cells. The nucleus is located centrally in principal cells and more apically in AMRC. AMRC are further divided into two histologically separable cell types: narrow cells, having a slender cytoplasm extending all the way from the basement membrane to the luminal edge, and apical cells, with a short cone-shaped morphology on the luminal side of the epithelium, with possibly no continuation to the basement membrane. The amount of AMRC decreases from caput to cauda (Palacios et al. 1991, Regadera et al. 1993). Different epididymal duct segments were categorized according to the classification of Holstein, briefly: types $2 \mathrm{a}$ and $\mathrm{b}$ are located in the caput and consist of tall columnar epithelium with regular outline and tall cilia. Both the cytoplasm and the cilia are taller in type $2 b$ than $2 a$. Type 3 tubules belong to the corpus. In type $3 \mathrm{a}$, the columnar epithelium becomes lower with shorter cilia. Small cysts formed by the epithelium appear in $3 \mathrm{~b}$ tubules, and in 3c these cysts become larger, more frequent, and may include spermatozoa. The outline of the epithelium transforms into irregular in 3b-c. Tubules located in the cauda epididymis are classified as types $4 a-c$. In $4 a$ tubules, the outline of the epithelium is irregular with no cysts, and the amount of cytoplasm diminishes when compared with the former segments. In $4 \mathrm{~b}$ tubules, the lumen gets remarkably wider and the epithelium lower. The epididymal lumen is at its widest in type 4c tubules, where the epithelium is at its lowest (Holstein 1969).

\section{Results}

\section{SLC26A2}

In all efferent ducts detected (types I-III), the cilia of the ciliated cells stained specifically for the anti-A2 antibody (Fig. 1J). In the epididymal ducts (types 2a-4a), all cell types remained negative for SLC26A2 (Fig. 2M and data not shown).

\section{SLC26A6}

The nonciliated cells of the types I and II efferent ducts gave strong positive signal for SLC26A6 on their apical edge (Fig. $1 \mathrm{~A}$ and $\mathrm{E}$ ), but the type III efferent ducts remained negative (Fig. 1A). In the epididymal ducts, a subgroup of AMRC was positive for SLC26A6 (Fig. 2A-C). Most of the narrow type AMRC and the early phase flat apical cells were negative, while the later phase apical cells extruding to the lumen stained apically (Fig. 2A-C). The epididymal tubules found in SLC26A6 stained samples were of types $2 \mathrm{a}-3 \mathrm{c}$, and positive AMRC were found in all of these tubule types detected (Fig. 2A-C and data not shown). The positive staining in the epididymal ducts was seen clearest with no pretreatment of the slides, whereas the signal in the efferent ducts required $10 \mathrm{~min}$ microwaving in citrate buffer to become visible. 

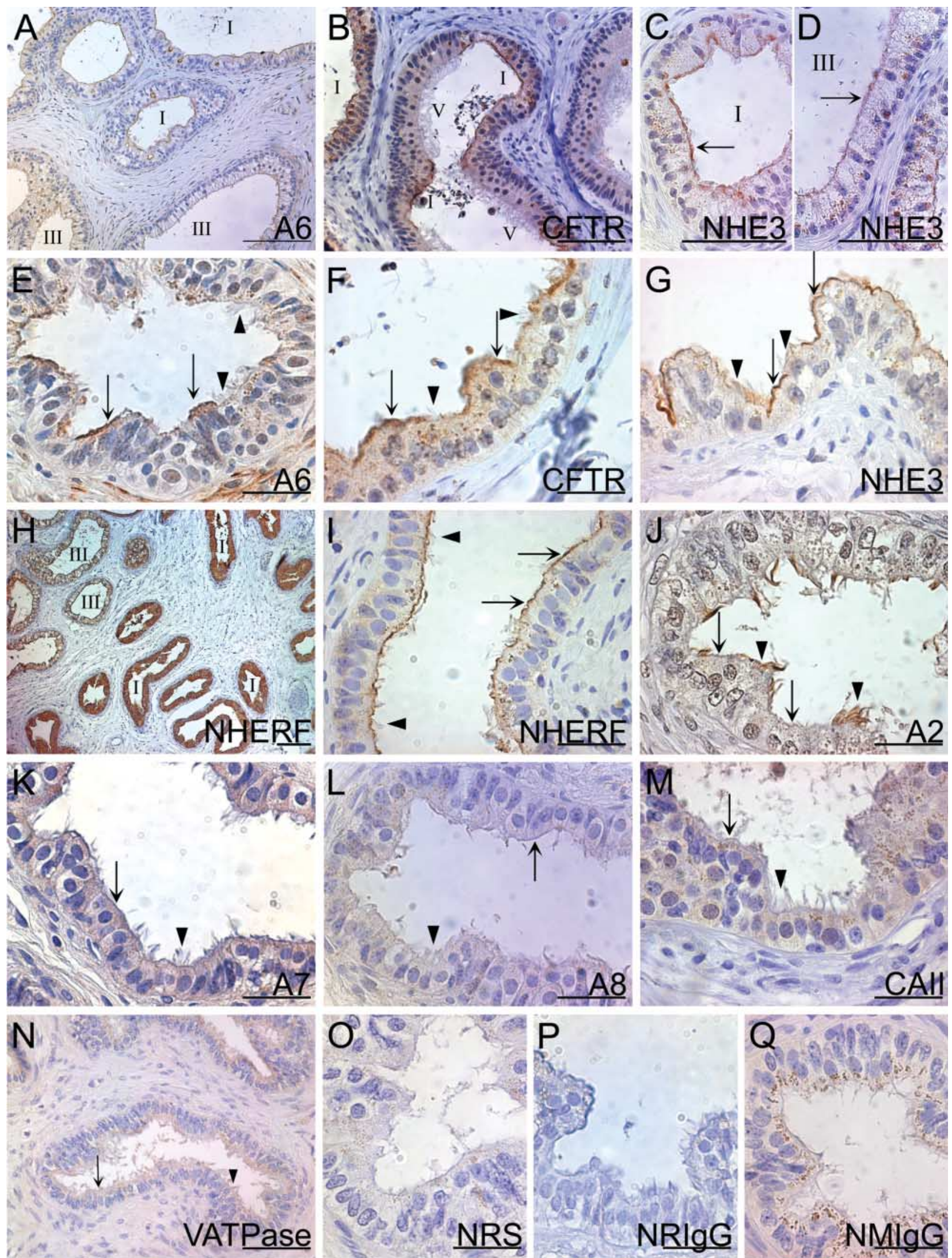


\section{SLC26A7}

All types of the efferent ducts were negative for anti-A7 antibody (Fig. 1K). However, SLC26A7 was detected in a subgroup of the basal cells in all the epididymal duct types found in the samples (duct types $2 \mathrm{a}-3 \mathrm{c}$ and $4 \mathrm{~b}-\mathrm{c}$; Fig. 2K-L and data not shown). The strong positive staining followed the cell membrane of these basal cells (Fig. 2L). Rest of the epididymal cell types remained unstained (Fig. 2K-L).

\section{SLC26A8}

The specificity of the anti-A8 serum was tested by western blot made of adult rat testis, known to express this protein (Toure et al. 2001). The anti-A8 serum detected a strong specific band of approximately $100 \mathrm{kDa}$ on the western blot made of adult rat testis (Fig. 3). This band corresponds well to the known 970 aa size of the SLC26A8 protein. In addition, a less intense $60 \mathrm{kDa}$ band was observed (Fig. 3). This is probably a degradation product of the SLC26A8 protein. Negative control stained with the corresponding rabbit preimmune serum remained negative (Fig. 3). Despite several different pretreatments and concentrations of antiserum used, the anti-A8 sera did not give any specific signal in the immunohistochemical stainings of human efferent ducts (Fig. 1L) or epididymal ducts (types 2a-4c, Fig. $2 \mathrm{O}$ and data not shown).

\section{CFTR}

The CFTR antibody gave a strong apical signal in the nonciliated cells of the efferent ducts, while the ciliated cells remained unstained (Fig. 1F). The staining was strongest in the types I (Fig. 1B and F) and II epithelium of the efferent ducts, and only a portion of the type III tubules stained for this antibody (data not shown), while type $V$ epithelium remained totally negative (Fig. 1B). In the epididymal ducts, a clear positive signal was seen on the apical border of the apical cells (Fig. 2D) of all duct types (2a-4a, 4c) detected (Fig. 2D and data not shown). The other cell types of the epididymal ducts remained negative (Fig. 2D).

\section{NHE3}

NHE3 gave a strong positive signal on the luminal edge of the nonciliated cells in the types I and II efferent ducts (Fig. 1C and G). In type III efferent ducts, faint staining could be seen in a few nonciliated cells, but the majority of ducts of this type were negative (Fig. 1D). All cell types in the epididymal ducts (types $2 \mathrm{a}-3 \mathrm{c}$ and $4 \mathrm{c}$ ) were negative for NHE3 antibody with all antigen retrieval methods used (Fig. $2 \mathrm{~N}$ and data not shown).

\section{NHERF-1}

NHERF-1 was found on the apical aspect of virtually all of the efferent duct cells, both ciliated and nonciliated, in all different epithelium types detected (Fig. $1 \mathrm{H}-\mathrm{I})$. The signal was generally slightly stronger in the nonciliated than the ciliated cells. In the epididymal ducts, NHERF-1 was found in the cytoplasm of the narrow and apical forms of AMRCs and in a few basal cells in duct types 2a-3c (Fig. 2E-F and data not shown). Only very few type 4a epididymal tubules were found in the samples studied, and they included no NHERF-1 signal (data not shown). However, considering the small amount of the detected 4 a tubules and the low AMRC count in the distal epididymis, no reliable conclusion about the absence of NHERF-1 in the distal epididymis can be made based on these results.

\section{V-ATPase}

All types of the efferent duct epithelium lacked V-ATPase signal (Fig. 1N). Instead, it was clearly detected both in the narrow and the apical forms the AMRC of the epididymal ducts (Fig. 2I-J) in all duct types (2a-4c; Fig. 2I-J and data not shown). Both the antibody against $B$ and the one against $E$ subunit of V-ATPase gave similar results (data not shown).

\section{CAII}

All human efferent duct types were negative for the antiCAll antibody (Fig. 1M). In the types $2 \mathrm{a}-3 \mathrm{c}$ and $4 \mathrm{c}$, epididymal ducts found in the CAll-stained samples (Fig. 2G-H and data not shown), the apical and narrow cells showed cytoplasmic signal for the CAll (Fig. 2G-H).

\footnotetext{
Figure 1 Immunohistochemical stainings of human efferent ducts. (A) Anion transporter SLC26A6 (A6) is expressed in the type I but not in the vacuolated type III efferent ducts. (B) $\mathrm{Cl}^{-}$channel CFTR is located to the type I but not in the type $\mathrm{V}$ efferent ducts. (C) Sodium/proton exchanger 3 (NHE3) is clearly positive in type I efferent ducts (arrow), while (D) in type III vacuolated efferent ducts NHE3 staining is very faint (arrow). With higher magnification, it is evident that (E) SLC26A6, (F) CFTR, and (G) NHE3 are all located to the apical face of the nonciliated cells (arrows) and the ciliated cells remain negative (arrowheads) for all these three antibodies. $(\mathrm{H}) \mathrm{NHE} 3$ regulatory factor 1 (NHERF) is expressed both in types I and III efferent ducts. (I) Higher magnification from type II efferent duct reveals that all of the nonciliated cells (arrows) and the majority of the ciliated cells (arrowheads) are positive for NHERF-1 antibody. (J) Anion transporter SLC26A2 (A2) is detected specifically in the cilia of the ciliated cells (arrowheads). The nonciliated cells are negative for this protein (arrows). Stainings for anion transporters (K) SLC26A7 and (L) SLC26A8, as well as (M) CAll and (N) vacuolar-type $\mathrm{H}^{+}$ATPase subunit B (VATPase) remained negative for both ciliated (arrowheads) and nonciliated (arrows) cells. Negative controls stained with (O) normal rabbit serum (NRS), (P) normal rabbit serum's IgG fraction (NRIgG) and (Q) normal mouse serum's IgG fraction (NMIgG) remained negative in all experiments. Scale bars: A and H, $100 \mu \mathrm{m} ; \mathrm{B}-\mathrm{D}$ and N, $50 \mu \mathrm{m}$; E-G, I-M and O-Q, $20 \mu \mathrm{m}$.
} 

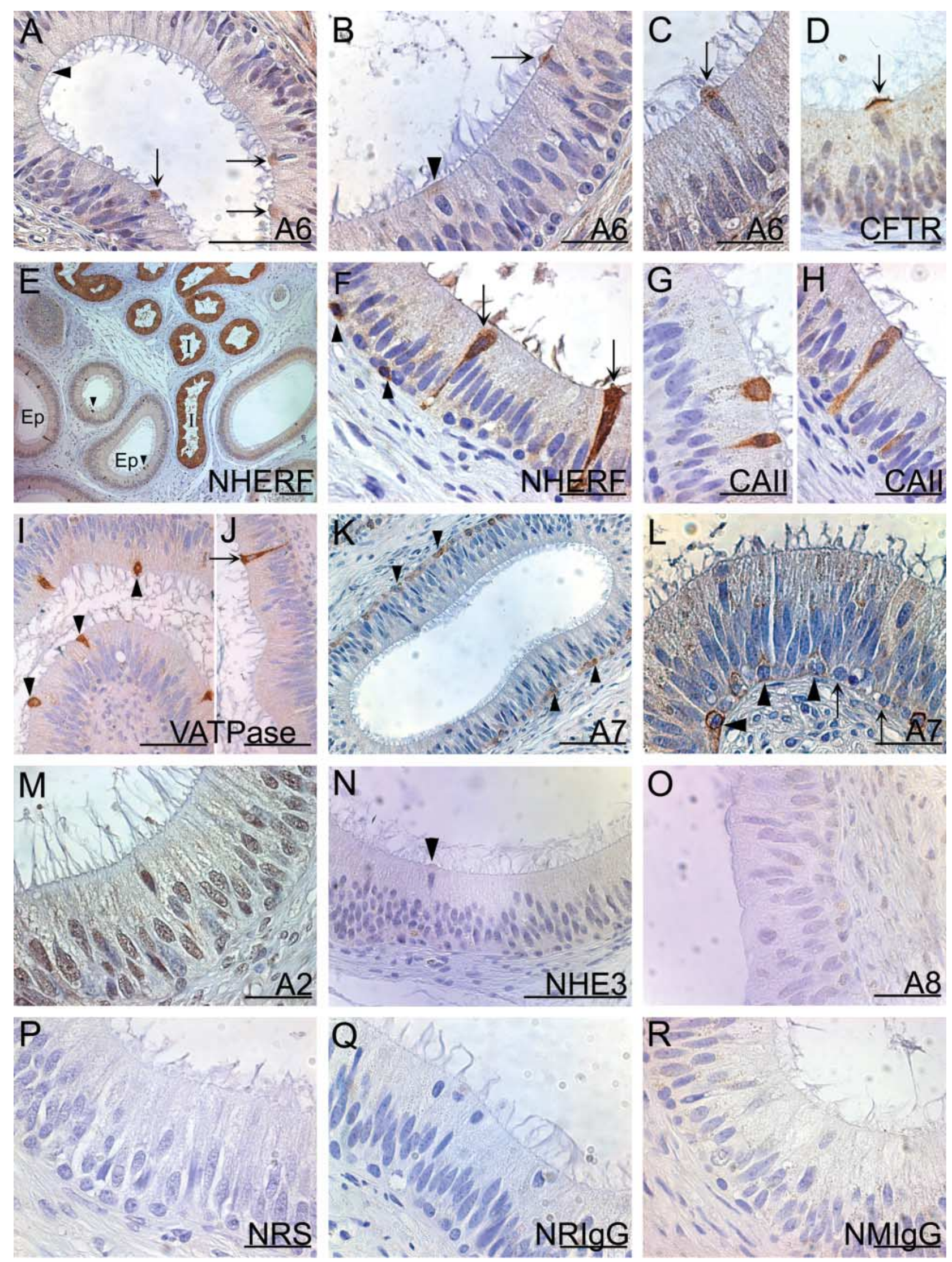


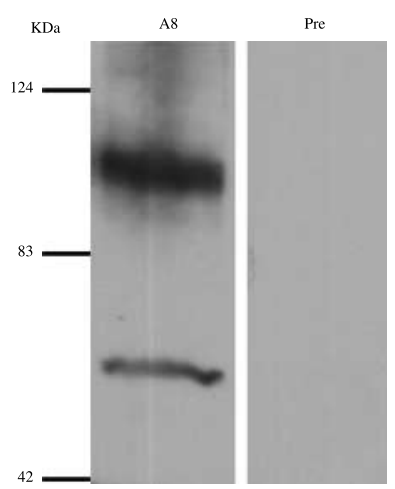

Figure 3 Western blot made of normal rat testis and stained with antihuman SLC26A8 antiserum (A8) or the corresponding preimmune serum (Pre). The anti-A8 serum detected a strong specific band of approximately $100 \mathrm{kDa}$, which corresponds well to the known 970 aa size of the SLC26A8 protein. In addition, a less intense circa $60 \mathrm{kDa}$ band is seen. This is probably a degradation product of the SLC26A8 protein. Negative control (Pre) remained totally negative.

Other epididymal cell types remained negative for this antibody (Fig. 2G-H).

\section{Discussion}

Many complex physiological processes take place in the male efferent and epididymal ducts, but little is still known about the particular roles of the various cell types and proteins expressed by them. In this study, we immunolocalized for the first time the anion exchanger proteins SLC26A2, A6, and A7 and the regulatory protein NHERF-1 in the efferent and epididymal ducts, and further characterized the expression of CFTR, NHE3, and V-ATPase in these structures in human, and compared their localization with that of CAII.

At molecular level, the studies of regulatory domains of distinct transporters have revealed complex interaction networks linking specific transporters spatially together, enabling, e.g. their reciprocal regulation. As an example, binding of the sulfate transporter and anti-sigma factor antagonist (STAS) domain of the SLC26 family members SLC26A3 and A6 with the $\mathrm{R}$ domain of the $\mathrm{Cl}^{-}$channel CFTR, promotes activation of both proteins, which is further facilitated by their PDZ ligands (Ko et al. 2004). The regulator NHERF- 1 is an apical PDZ protein shown to interact with SLC26A6, CFTR, the apical $\mathrm{Na}^{+} / \mathrm{H}^{+}$ exchanger NHE3, and B1 subunit of proton transporting V-ATPase (V-ATPaseB1; Weinman et al. 1995, Wang et al. 1998, Breton et al. 2000, Lohi et al. 2003), thus NHERF-1 may act as a shared spatial link for these transporters. Although only SLC26A6 of the SLC26 family members has been studied for NHERF-1 interactions so far, also SLC26A2, A3, A7, and A9 have consensus PDZ-binding sequences at their carboxyl terminus, offering a possibility to interact with PDZ networks (Lohi et al. 2002, 2003). Moreover, the $\mathrm{H}^{+}$and $\mathrm{HCO}_{3}^{-}$formation catalyst CAll was recently shown to form a transport metabolon with SLC26A6, affecting the $\mathrm{HCO}_{3}^{-}$transport activity of SLC26A6 (Alvarez et al. 2005).

This study shows that, in human efferent ducts, SLC26A6, CFTR, NHE3, and NHERF-1 are expressed on the apical edge of the nonciliated cells (Fig. 4), which are responsible for the major fluid reabsorption (Hess 2002). In addition, the anion transporter SLC26A3 has recently been located in these cells in human (Hihnala et al. 2006), enabling the proposed model of paired function of SLC26A3 and A6, activated by CFTR (Ko et al. 2002). Our results further coincide with the previous functional data from rat indicating that major absorption of $\mathrm{Cl}^{-}, \mathrm{Na}^{+}$, and water in the efferent ducts is mediated by an apical $\mathrm{Cl}^{-} / \mathrm{HCO}_{3}^{-}$exchanger, acting in parallel with a $\mathrm{Na}^{+} / \mathrm{H}^{+}$antiporter (Hansen et al. 2004). Thus, we propose a model that in human efferent ducts, SLC26A3 and A6 work in conjunction with CFTR to secret $\mathrm{HCO}_{3}^{-}$and absorb $\mathrm{Cl}^{-}$, and this action is further facilitated by the $\mathrm{Na}^{+}$absorption of the $\mathrm{Na}^{+} / \mathrm{H}^{+}$ exchanger NHE3. All of these transporters may be regulated and spatially linked by NHERF-1, also localized in the nonciliated cells. Interestingly, estrogen regulates SLC26A3, NHE3, CFTR, and NHERF-1 (Rochwerger \& Buchwald 1993, Ediger et al. 1999, Lee et al. 2001, Zhou et al. 2001, Ediger et al. 2002), further suggesting that these proteins may form a functional unit. Whether SLC26A6 is also regulated by estrogen, remains to be clarified.

\footnotetext{
Figure 2 Immunohistochemical stainings of human epididymal ducts. (A-C) Anion transporter SLC26A6 (A6) is positive in the out bulging forms of apical cells (arrows), while the flat apical cells (arrowheads) are negative. The more the cell is bulging into the lumen, the more positive the staining tends to be. The positive signal is concentrated on the apical face of the cells. (D) $\mathrm{Cl}^{-}$channel CFTR gives a strong apical signal in the apical cells (arrow). (E) A low magnification picture showing an overview of both efferent ducts type I (I) and epididymal ducts (Ep) stained with NHE3 regulatory factor 1 (NHERF). E-F) NHERF gives strong pancytoplasmic staining in both apical (arrowheads in (E) and narrow (arrows in (F) types of AMRC. In addition, few basal cells are stained (arrowheads in (F)). (G-H) CAll was detected in the cytoplasm of both (G) apical and (H) narrow forms of AMRC. (IJ) Vacuolar-type $\mathrm{H}^{+}$ATPase subunit B (VATPase) is positive in all AMRC as well, both in apical (arrowheads) and narrow (arrow) cell types. The staining is mainly pancytoplasmic, but in some cells apical concentration could be seen (arrow). ( $\mathrm{K}$ and L) Anion transporter SLC26A7 (A7) is located to a subgroup of the basal cells (arrowheads). Some of the basal cells are negative for this protein (arrows). (M) Anion transporter SLC26A2 (A2) is not detected in any epididymal cell types. (N) NHE3 is negative in all cells of human epididymal ducts, including the apical cells (arrowhead). (O) Antibody against anion transporter SLC26A8 (A8) leaves all cells of human epididymal ducts negative. (P-R) Negative controls stained with (P) normal rabbit serum (NRS), (Q) normal rabbit serum's IgG fraction (NRIgG), and (R) normal mouse serum's IgG fraction (NMlgG) remained negative in all experiments. The epididymal tubule types shown here (classified according to Holstein, 1969): A, C and Q, type 2a; E, M-N, Pand R, 2b; B, D, F-H, K-L and $\mathrm{O}, 3 \mathrm{a}$; I-J, 3b. Scale bars: A, I-K and N, $50 \mu \mathrm{m} ; \mathrm{B}-\mathrm{D}, \mathrm{F}-\mathrm{H}, \mathrm{L}-\mathrm{M}$ and $\mathrm{O}-\mathrm{R}, 20 \mu \mathrm{m} ; \mathrm{E}, 100 \mu \mathrm{m}$.
} 

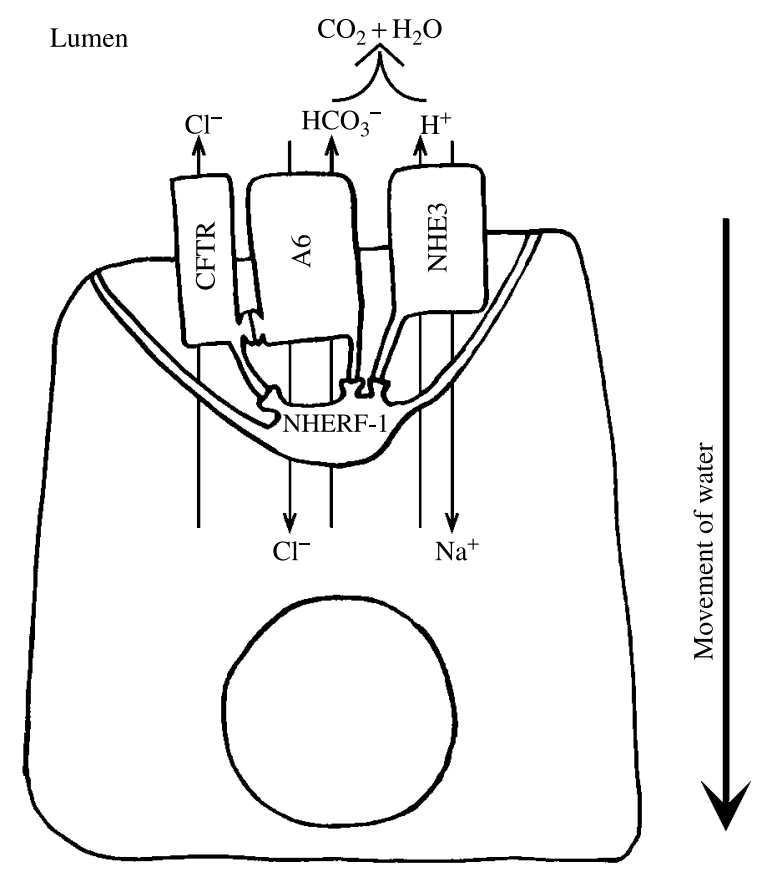

Figure 4 A diagram of the possible interactions of SLC26A6 (A6), CFTR, NHE3, and NHERF-1 in a nonciliated cell of the efferent ducts of the human epididymis.

In contrast to the other proteins studied, expression of the SLC26A2 protein was found strictly in the cilia of the ciliated cells in the efferent ducts. As an epithelial $\mathrm{Cl}^{-} / \mathrm{SO}_{4}^{2-}$ exchanger (Satoh et al. 1998), its putative role in the male reproductive tract is less clear. However, diastrophic dysplasia male patients with mutations in SLC26A2 have not been reported to be subfertile, thus the function of SLC26A2 in male fertility may be less crucial than SLC26A3's, which causes male subfertility when mutated (Hoglund et al. 2006).

In the epididymal ducts, we found co-expression of SLC26A6, CFTR, NHERF-1, CAIl, and B and E subunits of V-ATPase in the AMRC (Fig. 5), while SLC26A7 was localized in a subgroup of basal cells. Strict control of luminal $\mathrm{HCO}_{3}^{-}$concentration by epididymal epithelium is essential to avoid premature sperm motility, membrane instability and thus impaired fertility (Litvin et al. 2003, Gadella \& Van Gestel 2004). AMRC have been suggested to have a critical part in regulating the intraluminal $\mathrm{pH}$ in human epididymal ducts (Palacios et al. 1991), which would coincide with localization of $\mathrm{HCO}_{3}^{-}$transporting SLC26A6, proton transporting V-ATPase, and CAll that catalyzes formation of these ions and affects the activity of $\mathrm{HCO}_{3}^{-}$transport by SLC26A6 (Alvarez et al. 2005) in this cell type.

Expression of the SLC26A7 protein, a transporter for $\mathrm{Cl}^{-}, \mathrm{SO}_{4}^{2-}$, and oxalate (Lohi et al. 2002), was found in a subgroup of basal cells of the human epididymal ducts. Physiological function of the basal cells is unclear; roles in regulation of anion secretion of nearby principal cells

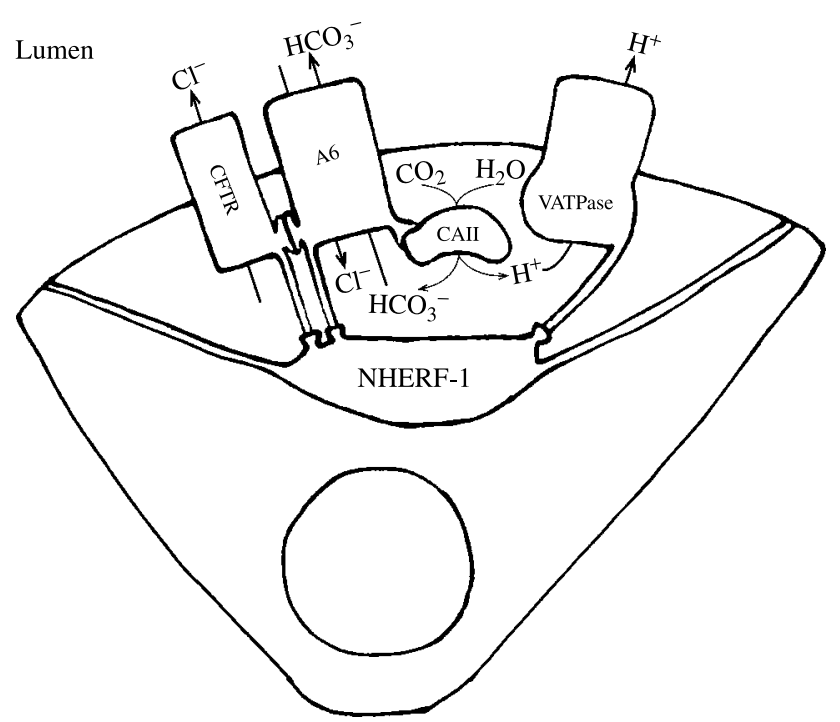

Figure 5 A diagram of SLC26A6 (A6), CFTR, CAII, NHERF-1, and VATPase in an apical form of AMRC of human epididymal ducts and their possible interactions.

and local immune defense have been proposed (Yeung et al. 1994, Cheung et al. 2005), and interestingly, SLC26A7 is also found in the nonspecific defense cells, macrophages (Kujala unpublished observations). However, the detailed function of SLC26A7 in these processes is yet to be clarified.

The localization of some of the proteins studied here in human differs partly from the earlier studies in rodents. Unexpectedly, none of the proteins were found in the principal cells of human epididymal ducts. For instance, CFTR was located specifically on the apical border of the apical form of AMRC in human, while earlier findings showed immunolocalization in the principal and clear cells of the epididymis in rats (Ruz et al. 2004). However, in efferent ducts, CFTR was found in the apical surface of the nonciliated cells in human, similarly as previously shown for rat (Ruz et al. 2004). In rat, NHE3 is found on the apical pole of the nonciliated cells of the efferent ducts and principal cells of the epididymal ducts (Pushkin et al. 2000, Bagnis et al. 2001, Kaunisto et al. 2001, Leung et al. 2001, Kaunisto \& Rajaniemi 2002), while we found it only in the former in human. Rat V-ATPase is expressed widely in the male reproductive tract, e.g., in the efferent ducts and epididymis, (Herak-Kramberger et al. 2001) but the human ortholog was found in AMRC of epididymal ducts only. Based on functional data derived from rodents, NHEs may be more important in the proximal parts of epididymis, whereas V-ATPase in more distal structures (Breton et al. 1996, Bagnis et al. 2001, Herak-Kramberger et al. 2001, Yeung et al. 2004), which would be in harmony with our immunohistochemical data.

Discrepancies in the transporter expression profiles between different species make functional differences possible on tissue level. Unfortunately, relevant 
functional studies in human reproductive tract are, and will be, challenging. However, our immunohistochemical results together with previous functional data suggest that the proteins studied in this work may form interaction units in the human epididymis, and possibly affect human male fertility, if mutated.

\section{Acknowledgements}

The authors wish to thank Matti Vierula PhD for valuable discussions about the histology of the epididymis and Siru Mäkelä MD PhD for advice on the SLC26A2 antibodies. Mrs Ranja Eklund and Mrs Riitta Känkänen are thanked for their excellent technical assistance. Marcus Nyberg MD is acknowledged for helping with the tissue samples. The authors declare that there is no conflict of interest that would prejudice the impartiality of this scientific work.

\section{Funding}

This study was supported by Biomedicum Helsinki Foundation, Clinical Research Fund of Helsinki University Central Hospital, Finnish Medical Foundation, Finska Läkaresällskapet, Foundation of Pediatric Research, Helsinki Biomedical Graduate School, Kidney Foundation, Research and Science Foundation of Farmos, Sigrid Juselius Foundation and The Finnish Cultural Foundation.

\section{References}

Alvarez BV, Vilas GL \& Casey JR 2005 Metabolon disruption: a mechanism that regulates bicarbonate transport. EMBO Journal $\mathbf{2 4}$ 2499-2511.

Bagnis C, Marsolais M, Biemesderfer D, Laprade R \& Breton S 2001 $\mathrm{Na}^{+} / \mathrm{H}^{+}$-exchange activity and immunolocalization of NHE3 in rat epididymis. American Journal of Physiology. Renal Physiology $\mathbf{2 8 0}$ F426-F436.

Breton S, Smith PJ, Lui B \& Brown D 1996 Acidification of the male reproductive tract by a proton pumping $\left(\mathrm{H}^{+}\right)$-ATPase. Nature Medicine 2 470-472.

Breton S, Wiederhold T, Marshansky V, Nsumu NN, Ramesh V \& Brown D 2000 The B1 subunit of the $\mathrm{H}^{+}$ATPase is a PDZ domainbinding protein. Colocalization with NHE-RF in renal B-intercalated cells. Journal of Biological Chemistry 275 18219-18224.

Chernova MN, Jiang L, Friedman DJ, Darman RB, Lohi H, Kere J, Vandorpe DH \& Alper SL 2005 Functional comparison of mouse slc26a6 anion exchanger with human SLC26A6 polypeptide variants: differences in anion selectivity, regulation, and electrogenicity. Journal of Biological Chemistry 280 8564-8580.

Cheung KH, Leung GP, Leung MC, Shum WW, Zhou WL \& Wong PY 2005 Cell-cell interaction underlies formation of fluid in the male reproductive tract of the rat. Journal of General Physiology 125 443-454.

Clulow J, Jones RC, Hansen LA \& Man SY 1998 Fluid and electrolyte reabsorption in the ductuli efferentes testis. Journal of Reproduction and Fertility Supplement 53 1-14.

Ediger TR, Kraus WL, Weinman EJ \& Katzenellenbogen BS 1999 Estrogen receptor regulation of the $\mathrm{Na}^{+} / \mathrm{H}^{+}$exchange regulatory factor. Endocrinology 140 2976-2982.

Ediger TR, Park SE \& Katzenellenbogen BS 2002 Estrogen receptor inducibility of the human $\mathrm{Na}^{+} / \mathrm{H}^{+}$exchanger regulatory factor/ezrin-radixin-moesin binding protein 50 (NHE-RF/EBP5O) gene involving multiple half-estrogen response elements. Molecular Endocrinology 16 1828-1839.

Everett LA, Glaser B, Beck JC, Idol JR, Buchs A, Heyman M, Adawi F, Hazani E, Nassir E, Baxevanis AD et al. 1997 Pendred syndrome is caused by mutations in a putative sulphate transporter gene (PDS). Nature Genetics 17 411-422.

Gadella BM \& Van Gestel RA 2004 Bicarbonate and its role in mammalian sperm function. Animal Reproduction Science 82-83 307-319.

Haila S, Saarialho-Kere U, Karjalainen-Lindsberg ML, Lohi H, Airola K, Holmberg C, Hastbacka J, Kere J \& Hoglund P 2000 The congenital chloride diarrhea gene is expressed in seminal vesicle, sweat gland, inflammatory colon epithelium, and in some dysplastic colon cells. Histochemistry and Cell Biology 113 279-286.

Haila S, Hastbacka J, Bohling T, Karjalainen-Lindsberg ML, Kere J \& Saarialho-Kere U 2001 SLC26A2 (diastrophic dysplasia sulfate transporter) is expressed in developing and mature cartilage but also in other tissues and cell types. Journal of Histochemistry and Cytochemistry 49 973-982.

Hansen LA, Dacheux F, Man SY, Clulow J \& Jones RC 2004 Fluid reabsorption by the ductuli efferentes testis of the rat is dependent on both sodium and chlorine. Biology of Reproduction 71 $410-416$.

Hastbacka J, de la Chapelle A, Mahtani MM, Clines G, Reeve-Daly MP, Daly M, Hamilton BA, Kusumi K, Trivedi B, Weaver A et al. 1994 The diastrophic dysplasia gene encodes a novel sulfate transporter: positional cloning by fine-structure linkage disequilibrium mapping. Cell 78 1073-1087.

Herak-Kramberger CM, Breton S, Brown D, Kraus O \& Sabolic I 2001 Distribution of the vacuolar $\mathrm{H}^{+}$atpase along the rat and human male reproductive tract. Biology of Reproduction 64 1699-1707.

Hess RA 2002 The efferent ductules: structure and function. In The Epididymis: from Molecules to Clinical Practice, pp 49-80. Eds B Robaire \& BT Hinton. Dordrecht/New York: Kluwer Academic/ Plenum Publishers.

Hihnala S, Kujala M, Toppari J, Kere J, Holmberg C \& Hoglund P 2006 Expression of SLC26A3, CFTR and NHE3 in the human male reproductive tract: role in male subfertility caused by congenital chloride diarrhoea. Molecular Human Reproduction 12 107-111.

Hoglund P, Haila S, Socha J, Tomaszewski L, Saarialho-Kere U, Karjalainen-Lindsberg ML, Airola K, Holmberg C, de la Chapelle A \& Kere J 1996 Mutations of the down-regulated in adenoma (DRA) gene cause congenital chloride diarrhoea. Nature Genetics 14 316-319.

Hoglund P, Hihnala S, Kujala M, Tiitinen A, Dunkel L \& Holmberg C 2006 Disruption of the SLC26A3-mediated anion transport is associated with male subfertility. Fertility and Sterility 85 232-235.

Holstein A-F 1969 In Morphologische Studien am Nebenhoden des Menschen, 1 edn, pp 1-91. Eds W Bargmann \& W Doerr. Stuttgart: Georg Thieme Verlag.

Kaunisto KM \& Rajaniemi HJ 2002 Expression and localization of the $\mathrm{Na}^{+} / \mathrm{H}^{+}$exchanger isoform NHE3 in the rat efferent ducts. Journal of Andrology 23 237-241.

Kaunisto K, Moe OW, Pelto-Huikko M, Traebert M \& Rajaniemi H 2001 An apical membrane $\mathrm{Na}^{+} / \mathrm{H}^{+}$exchanger isoform, $\mathrm{NHE}-3$, is present in the rat epididymal epithelium. Pflugers Archiv $\mathbf{4 4 2}$ 230-236.

Ko SB, Shcheynikov N, Choi JY, Luo X, Ishibashi K, Thomas PJ, Kim JY, Kim KH, Lee MG, Naruse S et al. 2002 A molecular mechanism for aberrant CFTR-dependent $\mathrm{HCO}^{3-}$ transport in cystic fibrosis. $\mathrm{EMBO}$ Journal 21 5662-5672.

Ko SB, Zeng W, Dorwart MR, Luo X, Kim KH, Millen L, Goto H, Naruse S, Soyombo A, Thomas PJ et al. 2004 Gating of CFTR by the STAS domain of SLC26 transporters. Nature Cell Biology 6 343-350. 
Kujala M, Tienari J, Lohi H, Elomaa O, Sariola H, Lehtonen E \& Kere J 2005 The SLC26A6 and SLC26A7 anion exchangers have distinct distribution in human kidney. Nephron. Experimental Nephrology 101 e50-e58.

Lacroix L, Mian C, Caillou B, Talbot M, Filetti S, Schlumberger M \& Bidart JM $2001 \mathrm{Na}^{+} / \mathrm{I}^{-}$symporter and Pendred syndrome gene and protein expressions in human extra-thyroidal tissues. European Journal of Endocrinology 144 297-302.

Lee KH, Finnigan-Bunick C, Bahr J \& Bunick D 2001 Estrogen regulation of ion transporter messenger RNA levels in mouse efferent ductules are mediated differentially through estrogen receptor (ER) alpha and ER beta. Biology of Reproduction 65 1534-1541.

Leung GP, Tse CM, Chew SB \& Wong PY 2001 Expression of multiple $\mathrm{Na}^{+} / \mathrm{H}^{+}$exchanger isoforms in cultured epithelial cells from rat efferent duct and cauda epididymidis. Biology of Reproduction 64 $482-490$.

Levine N \& Kelly H 1978 Measurement of $\mathrm{pH}$ in the rat epididymis in vivo. Journal of Reproduction and Fertility 52 333-335.

Levine N \& Marsh DJ 1971 Micropuncture studies of the electrochemical aspects of fluid and electrolyte transport in individual seminiferous tubules, the epididymis and the vas deferens in rats. Journal of Physiology 213 557-570.

Litvin TN, Kamenetsky M, Zarifyan A, Buck J \& Levin LR 2003 Kinetic properties of 'soluble' adenylyl cyclase. Synergism between calcium and bicarbonate. Journal of Biological Chemistry 278 15922-15926.

Liu X, Ouyang X, Xia X, Zheng J, Pandaya A, Li F, Du L, Welch K, Petit C, Smith RJ et al. 2003 Prestin, a cochlear motor protein, is defective in non-syndromic hearing loss. Human Molecular Genetics 12 1155-1162.

Lohi H, Kujala M, Kerkelä E, Saarialho-Kere U, Kestilä M \& Kere J 2000 Mapping of five new putative anion transporter genes in human and characterization of SLC26A6, a candidate gene for pancreatic anion exchanger. Genomics 70 102-112.

Lohi H, Kujala M, Makela S, Lehtonen E, Kestila M, Saarialho-Kere U, Markovich D \& Kere J 2002 Functional characterization of three novel tissue-specific anion exchangers SLC26A7, -A8, and -A9. Journal of Biological Chemistry 277 14246-14254.

Lohi H, Lamprecht G, Markovich D, Heil A, Kujala M, Seidler U \& Kere J 2003 Isoforms of SLC26A6 mediate anion transport and have functional PDZ interaction domains. American Journal of Physiology. Cell Physiology 284 C769-C779.

Newcombe N, Clulow J, Man SY \& Jones RC $2000 \mathrm{pH}$ and bicarbonate in the ductuli efferentes testis of the rat. International Journal of Andrology 23 46-50.

Palacios J, Regadera J, Nistal M \& Paniagua R 1991 Apical mitochondria-rich cells in the human epididymis: an ultrastructural, enzymohistochemical, and immunohistochemical study. Anatomical Record 231 82-88.

Pushkin A, Clark I, Kwon TH, Nielsen S \& Kurtz I 2000 Immunolocalization of $\mathrm{NBC} 3$ and $\mathrm{NHE} 3$ in the rat epididymis: colocalization of $\mathrm{NBC} 3$ and the vacuolar $\mathrm{H}^{+}$-ATPase. Journal of Andrology 21 708-720.

Regadera J, Cobo P, Paniagua R, Martinez-Garcia F, Palacios J \& Nistal M 1993 Immunohistochemical and semiquantitative study of the apical mitochondria-rich cells of the human prepubertal and adult epididymis. Journal of Anatomy 183 507-514.
Regeer RR, Lee A \& Markovich D 2003 Characterization of the human sulfate anion transporter (hsat-1) protein and gene (SAT1; SLC26A1). DNA and Cell Biology 22 107-117.

Rochwerger L \& Buchwald M 1993 Stimulation of the cystic fibrosis transmembrane regulator expression by estrogen in vivo. Endocrinology 133 921-930.

Ruz R, Andonian S \& Hermo L 2004 Immunolocalization and regulation of cystic fibrosis transmembrane conductance regulator in the adult rat epididymis. Journal of Andrology 25 265-273.

Satoh H, Susaki M, Shukunami C, lyama K-I, Negoro T \& Hiraki Y 1998 Functional analysis of diastrophic dysplasia sulfate transporter. Journal of Biological Chemistry 273 12307-12315.

Toure A, Morin L, Pineau C, Becq F, Dorseuil O \& Gacon G 2001 Tat1, a novel sulfate transporter specifically expressed in human male germ cells and potentially linked to rhogtpase signaling. Journal of Biological Chemistry 276 20309-20315.

Turner TT 2002 Necessity's potion: inorganic and small organic molecules in the epididymal lumen. In The Epididymis: from Molecules to Clinical Practice, pp 131-150. Eds B Robaire \& BT Hinton. Dordrecht/New York: Kluwer Academic/Plenum Publishers.

Wang S, Raab RW, Schatz PJ, Guggino WB \& Li M 1998 Peptide binding consensus of the NHE-RF-PDZ1 domain matches the C-terminal sequence of cystic fibrosis transmembrane conductance regulator (CFTR). FEBS Letters 427 103-108.

Weinman EJ, Steplock D, Wang Y \& Shenolikar S 1995 Characterization of a protein cofactor that mediates protein kinase $\mathrm{A}$ regulation of the renal brush border membrane $\mathrm{Na}\left({ }^{+}\right)-\mathrm{H}^{+}$ exchanger. Journal of Clinical Investigation 95 2143-2149.

Wong PYD, Gong XD, Leung GPH \& Cheuk BLY 2002 Formation of the epididymal fluid microenvironment. In The Epididymis: from Molecules to Clinical Practice, pp 119-130. Eds B Robaire \& BT Hinton. Dordrecht/New York: Kluwer Academic/Plenum Publishers.

Yeung CH, Cooper TG, Bergmann M \& Schulze H 1991 Organization of tubules in the human caput epididymidis and the ultrastructure of their epithelia. American Journal of Anatomy 191 261-279.

Yeung CH, Nashan D, Sorg C, Oberpenning F, Schulze H, Nieschlag E \& Cooper TG 1994 Basal cells of the human epididymis-antigenic and ultrastructural similarities to tissue-fixed macrophages. Biology of Reproduction 50 917-926.

Yeung CH, Breton S, Setiawan I, Xu Y, Lang F \& Cooper TG 2004 Increased luminal $\mathrm{pH}$ in the epididymis of infertile c-ros knockout mice and the expression of sodium-hydrogen exchangers and vacuolar proton pump $\mathrm{H}^{+}$-ATPase. Molecular Reproduction and Development 68 159-168.

Zhou Q, Clarke L, Nie R, Carnes K, Lai LW, Lien YH, Verkman A, Lubahn D, Fisher JS, Katzenellenbogen BS et al. 2001 Estrogen action and male fertility: roles of the sodium/hydrogen exchanger-3 and fluid reabsorption in reproductive tract function. PNAS $\mathbf{9 8}$ 14132-14137.

Received 13 September 2005

First decision 17 November 2005

Revised manuscript received 12 December 2006

Accepted 5 January 2007 